\title{
Approaches to writing a social history of Dutch in Japan
}

\begin{abstract}
To date there has been no social history of the interesting subject of the Dutch language in Japan from c.1600 to 1900. This article provides a brief introduction to the use of Dutch in Japan, and then considers three possible approaches to writing such a history, evaluating the merits of each approach. The first of these is to analyse the use of Dutch in Japan by communities of language. The second approach is domain-based. This approach considers the use of language within social domains or spheres of activity, such as commerce and education. The third approach is a functionbased one, which focusses on the purpose(s) for which individuals and groups used Dutch. These include functions such as translation and interpretation. The article concludes that given the particularity of the use of Dutch in Japan, it may be better to use aspects of each approach in writing a social history on this subject.
\end{abstract}

\section{Introduction}

The history of the Dutch in Japan between about 1600 and 1900 has received a significant amount of scholarly attention in recent years from authors such as Wim Boot, Reinier Hesselink and Adam Clulow. However, whilst the history of the Dutch language in other parts of the world, such as Indonesia, has received some attention, the history of the language in Japan has received much less attention, in particular from historians of the Dutch language ${ }^{1}$. This article begins to address

${ }^{1}$ For a history of Dutch in Indonesia, see Groeneboer (1998). In their accounts of the history of the Dutch language, van der Wal and van Bree (2008) do not discuss Japan at all, whilst Willemyns (2013) only devotes half a page to the subject. One Japanologist who has written on the history of Dutch in Japan is Henk de Groot. His unpublished PhD thesis (De Groot 2005) provides a number of valuable insights, some of which are referred to in this article. However, the focus of this work is the process by and materials with which the Japanese learnt Dutch. By contrast, the project described in the present article will examine how Dutch was used in different social contexts in Japan. Furthermore, De Groot's work makes little reference to sociolinguistic literature or other literature on the history of the Dutch language. 
this situation by considering what a social history of Dutch in Japan might look like. It offers three possible approaches to writing such a history.

One approach is to consider which communities of language were using Dutch and the manner in which they were using it. Three principal communities of language can be identified in this regard; the Dutch and other Europeans; Japanese scholars who pursued 'Dutch studies' (Japanese: rangaku); and Japanese interpreters, who in some sense acted as linguistic go-betweens for their fellowcountrymen and the Dutch ${ }^{2}$.

A second approach is to analyse the use of Dutch in Japan by social domain or sphere of activity. This considers who spoke or wrote the language to whom, and why, in each domain. Amongst the social domains in which Dutch was used in Japan are commerce, learning, the home, local government, and the court at the capital of the Tokugawa Shogunate (1603-1867), Edo (now Tokyo) ${ }^{3}$.

A third approach is to consider the various functions that Dutch was used to perform in Japan. One of the main challenges in writing a social history of this nature is that the language was used in very different ways by members of the communities of language just mentioned. For example, whilst many of the Dutch and other Europeans used the language for everyday communication and conducting business, the Japanese scholars who pursued 'Dutch studies' (rangakusha) used their knowledge of the language primarily for the purpose of reading and translating into Japanese.

After an examination of these three approaches, consideration is given to whether it may be necessary to combine aspects of each of them in order to provide a comprehensive social history of Dutch in Japan. First, however, a brief history of the Dutch in Japan is provided for those readers unfamiliar with this subject, in order to give the necessary context for the rest of the article.

\section{The Dutch in Japan: a brief introduction}

The history of Dutch in Japan can be divided very roughly into four periods. The first period, 1600-1700, marks the arrival of Dutch in Japan and the eventual shift from Portuguese to Dutch by Japanese interpreters. In the second period, 17001800, Japanese scholars began to take an active interest in books written in Dutch and to translate them into Japanese. The third period, which is roughly 1800-

2 The first syllable of the term rangaku derives from the second syllable of the Portuguese word for 'Holland', Oranda, whilst gaku means 'study' or 'learning' in Japanese. It is in fact a broad term that covers the study in Japan not only of books written in Dutch but also of translations into Dutch and Chinese translations of them. In the late nineteenth century the term was replaced by yōgaku ('Western learning').

${ }^{3}$ This article does not use macrons for Japanese names which have an established English form, such as Tokyo and Osaka. For other Japanese words, macrons are used. 
1850, marks the apogee of Dutch in Japan. Schools dedicated to rangaku were opened, thousands of books were translated from Dutch into Japanese and study aids, such as grammars and dictionaries, were produced to assist the Japanese who learnt Dutch. In the final period, 1850-1890, Dutch flourished briefly as the lingua franca for the Japanese and other Westerners, who arrived in Japan from 1853/54 onwards. However, by 1890 Dutch had been eclipsed by other Western languages and rangaku had more or less run its course.

\section{1. $1600-1700$}

The Dutch language arrived in Japan in April 1600 on board the 'Liefde'4 This ship had set sail from Goeree in June 1598 with a crew of 110, but only 24 arrived in Japan, six of whom died shortly afterwards. It would be nine years before more sailors, whose first language was Dutch, reached Japan. They arrived on two Dutch East India Company (VOC) ships at Hirado on the West coast of Kyushu, where the Dutch were subsequently able to procure accommodation for a factory (De Lange 2006: 153, 243). ${ }^{5}$ Including the two ships that arrived in 1609, between 1609 and 1640221 Dutch vessels arrived at Hirado under the flag of the VOC (De Lange 2006: 214-215, 244). Each ship had around 100 men on board, about one half of whom would have had Dutch as their first language. So we can talk in terms of over 10,000 men (it was almost always men), whose first language was Dutch, coming to Hirado during this period.

In 1640 the Dutch were ordered to leave Hirado and remove to Nagasaki. A few years earlier an artificial island had been built for the Portuguese in Nagasaki Bay. However, they had been expelled from Japan in 1639 because the Japanese authorities objected to their proselytizing activities (De Lange 2006: 221). The Dutch would have their factory in Japan on the island in Nagasaki Bay, which came to be known as Deshima (lit. 'Island sticking out [into Nagasaki Bay]'), until it closed in 1860 .

For much of the seventeenth century, communication between the Dutch and the Japanese was often carried out via Portuguese. For example, in 1627 all documents exchanged between the Dutch and the Japanese had to pass through Portuguese (Clulow 2014: 275 n. 68). Although some interpreters spoke Dutch, much of the spoken communication between the Dutch and the Japanese at Hirado and in the first decades of the Dutch occupation of Deshima was also via Portuguese. Indeed, it was not until the early 1670s that the Governor of Nagasaki ordered

${ }^{4}$ In fact, one Dutchman, Dirk Gerritz. Pomp from Enkhuizen (1544-1604), had already visited Japan twice in the sixteenth century, aboard Portuguese ships. Whilst he may have made notes during his time there, he is unlikely to have spoken much, if any, Dutch (De Vries 2002).

5 The VOC was founded in 1602. The two ships were the 'Griffioen' and the 'Rode Leeuw met Pylen'. 
them explicitly to learn Dutch (Blussé et al. (eds.) 2000: 275; De Groot 2005: 24). The interpreters belonged to a College of interpreters (tsüji nakama; called a tolkencollege by the Dutch) (De Groot 2005: 3, n. 10). The numbers in the tsüji nakama are said to have reached as many as one hundred and fifty, despite the fact that there were rarely more than twenty Dutch at Deshima. However, whilst some of the interpreters had a good knowledge of the language, this was by no means the case for all of them (Vermeulen et al. (eds.) 1986-: X, 84).

One other point to make here is that the Dutch were not the only Europeans who went to Deshima. Several of the physicians who worked there in the seventeenth century were Germans. Amongst these we can name Caspar Schamberger (1623-1706), Engelbert Kaempfer (1651-1716), and Johannes Winsch from Erfurt, who became the senior surgeon at Deshima in 1651. Swedes also went to Japan. In the seventeenth century a Swedish army corporal, Juriaen Schedel, was at Deshima. Furthermore, we know that Schamberger, Kaempfer and Schedel visited Edo, on the hofreis ('court journey') to pay homage to the Shogun. These and other examples illustrate that Willemyns (2013:212) is wrong to say that Deshima was 'populated exclusively by Dutchmen'.

\section{2. $1700-1800$}

The spread of Dutch beyond the native speakers at Deshima and the Japanese interpreters to other parts of Japan was very slow. One reason for this was the persistence of Portuguese as a lingua franca in Japan. Another reason that has been advanced is that the interpreters were somewhat reluctant to share their knowledge of Dutch with other Japanese. De Groot (2005: 25-27) states that this was because the members of the tsüji nakama at Nagasaki were sworn in writing to protect 'national secrets', and, he goes on, we can assume that the Dutch language was one such secret. But despite these headwinds, Dutch began to spread beyond this small corner of Western Kyushu. One factor that probably helped in this regard was the lifting of a ban on certain categories of book in 1721 by the eighth Tokugawa Shogun, Yoshimune (ruled 1716-1745), who had a particular interest in astronomy ${ }^{6}$. However, a number of other factors also contributed to the gradual spread of Dutch in eighteenth-century Japan.

First, some of the interpreters at Nagasaki took a real step forward in their proficiency in Dutch. Second, they began, albeit very gradually, to share their

${ }^{6}$ The precise nature of the ban, introduced by the 1630 Edict of Kansei, is difficult to establish, as it is no longer extant. Kornicki argues that the Edict banned all European books regardless of content. However, Clements suggests the ban was limited to Western books associated with Christianity, notably thirty-two works from China by Matteo Ricci and other Europeans. She writes that Shogun Yoshimune lifted a ban specifically on the works from China by Ricci in 1721 (Clements 2015: 145, 180). Nevertheless, after this time, not only books by Ricci, but also books written in Dutch were imported into Japan in increasing numbers, albeit slowly at first. 
knowledge of Dutch with scholars who showed an interest in the subjects described in imported Dutch books, notably in the fields of medicine and astronomy. This led to the translation of Dutch books into Japanese and the emergence of rangaku. Indeed, some of the families from which the interpreters came, including the Yoshio, Motoki and Shizuki families, are also known to have engaged in scholarly research. In this regard we can mention Yoshio Kōgyū (also called Kōsaku), Motoki Ryōi and Shizuki Tadao (Sansom 1973: 201; Boot (ed.) 2008)7. Third, Shogun Yoshimune himself actively encouraged the study of the Dutch language (Nakamura 2005: 7). For example, in 1741 he sent the scholars Aoki Bunzō and Noro Genjō to Nagasaki in order to study the language. Bunzō wrote an account of the Dutch monetary system and some treatises on the Dutch language, whilst Genjō wrote a work on Dutch plants (Vos 1963: 343).

In 1774 a group of rangakusha published a Japanese translation of a Dutch translation (Ontleedkundige Tafelen ('Anatomical Tables' (1734))) of a Latin edition of a work by Johann Adam Kulmus. The Japanese translation took almost three and a half years to complete and was published as Kaitai Shinsho (lit. 'New Text on Anatomy'). In 1815, one of these rangakusha Sugita Genpaku (17331817) published an account of the trials and tribulations of this translation under the title Rangaku kotohajime ('The Beginnings of Dutch Learning'). By the end of the eighteenth century between ten and twenty works were being translated each year from Dutch to Japanese (Clements 2015: 147).

Towards the end of the eighteenth century schools were founded that were devoted to rangaku and materials were produced that facilitated the study of Dutch. Yoshio Kōgyū, mentioned above, who taught rangaku to Sugita Genpaku, ran a medical school, which enrolled six hundred students (Screech 1996: 15). In 1786 one of Genpaku's students and himself a leading rangakusha, Ōtsuki Gentaku (1757-1827) established a boarding school, the Shirando ('Herb and Orchid Hall'), for the study of rangaku and the Dutch language at Edo (Hesselink 1995: 204) $)^{8}$. In 1783 Gentaku wrote a primer of the Dutch language, Rangaku kaitei ('Guide to Dutch Learning') (Sansom 1973: 204). In 1796 thirty copies of the first edition of a Dutch-Japanese dictionary, the Haruma wage ('Halma Translated') were printed in Edo9. This was based on François Halma's Woordenboek der Nederduitsche en Fransche Taalen, published in 1708 (Clements 2015: $155-156)^{10}$.

${ }^{7}$ Shizuki Tadao is sometimes referred to as the 'patriarch of Dutch learning'.

8 The location of the Shirando changed several times, although it was always situated close to where the Dutch stayed when they visited Edo (Hesselink 1995: 204).

${ }^{9}$ It is also known as the Edo Haruma (Clements 2015: 156).

${ }^{10}$ For further details of Dutch books in Tokugawa Japan, see Rangaku Shiryō, Kenkyūkai (1957). 


\section{3. $1800-1850$}

In the nineteenth century, interest in rangaku continued to increase. More schools dedicated to it were opened and further study aids for learning Dutch were produced. Amongst the dictionaries, an abbreviated version of the Haruma wage was printed in 1810 (Clements 2015: 160) ${ }^{11}$. Another version of Halma's dictionary was compiled under the direction of the opperhoofd (1803-1817), Hendrik Doeff (1816). This became known as the Dōfu Haruma ('Doeff's Halma') or the Nagasaki Haruma. Shizuki Tadao (1760-1806), mentioned above, studied the Dutch language intensively, producing several grammars in manuscript. He was particularly inspired by Willem Sewel's Nederduytsche Spraakkonst (1708). One of his students, Baba Sajūrō, compiled a Dutch grammar in Japanese, Oranda bunpan tekiyō ('An Outline of Dutch Grammar') printed in 1814 (De Groot 2005: 144157). Furthermore, the number of translations from Dutch to Japanese increased to about twenty per year, peaking at more than fifty per year by the middle of the century (Clements 2015: 147, 160).

The German physician, Philipp Franz von Siebold (1796-1866), who posed, albeit not entirely successfully, as a Dutchman (officially the Dutch were still the only Westerners allowed to enter Japan), opened a medical school, the Narutakijuku at Narutaki close to Nagasaki, which had around fifty students (Sansom 1973: 260). Von Siebold gave lectures in Dutch once a week as well as carrying out various medical duties in Nagasaki. He required students to submit dissertations written in Dutch. One of his students was Takano Chōei (1804-1850). His Dutch-language skills were highly regarded. He would later write Seisetsu igen $s \bar{u} y \bar{o}$ ('Fundamentals of Western Medicine'), based in part on Dutch translations of medical works originally written in German and French. Chōei established a school for teaching Western medicine, the Daikandō in Edo (Nakamura 2005: 32-37).

In 1838 a Japanese physician, Ogata Kōan (1810-1863), established a rangaku school, called the Tekijuku, at Osaka. Amongst the students at Kōan's school in Osaka was Fukuzawa Yukichi (1835-1901). In 1858 Yukichi himself established a private rangaku school in Edo, which was the predecessor of Keiō University, founded in 1868. In fact we can talk in terms of thousands of students of Western medicine in Japan in the late eighteenth and nineteenth centuries. Aoki Toshiyuki has studied the origins of over 5,000 students on the rolls of 12 famous schools of Western medicine or ranpo ${ }^{12}$. He found that only one of Japan's 69 historical provinces had no students at these schools. This illustrates that knowledge

\footnotetext{
${ }^{11}$ Fujibayashi Fuzan's The Keys to Translation (Yakken).

12 This is as opposed to kanpō, or 'Chinese style' medicine. In reality, though, ranpō was a blend of Chinese and Western medicine.
} 
of the Dutch language spread far beyond western Kyushu and the capital city, Edo (Nakamura 2005: 100).

The desire of medical practitioners in Japan to understand Western medicine was one of the most significant reasons for Japanese wanting to gain a knowledge of Dutch. It was not only in schools such as the ones just discussed that those involved in medicine would engage with Dutch. Medical apprentices across Japan would live and work with their teachers for some seven to ten years. As part of their training in the late eighteenth and early nineteenth centuries, they would study Dutch as well as read the Chinese classics on medicine. In addition to running a school, Takano Chōei taught Dutch alongside Western medicine to a number of physicians and would-be physicians in situ, as it were. In return for his rangaku scholarship, they provided him with financial patronage (Nakamura 2005: 46, 85 $)^{13}$.

For a number of years, translations from Dutch into Japanese were made by personnel at the Astronomical Bureau in Edo, the Tenmonkata (De Groot 2005: 4). This illustrates well how the Japanese interest in Dutch books on astronomy played an important role in the development of rangaku. In 1811 the bakufu, or Shogunate government, established the Bansho Wage Goyo ('Bureau for the Translation of Foreign Books') at Asakusa, a district of Edo (Vos 1963: 345). This bureau took on translation work for which the personnel at the Tenmonkata had no time or appetite. The Bansho Wage Goyo acted as the official body for the translation of Dutch books into Japanese ${ }^{14}$.

The establishment of the Bansho Wage Goyō could be seen as an official attempt to control and manage the spread of Dutch learning. In the 1840s, in response to conservative forces, the Bureau undertook a censorship role (Montgomery 2000: 215). Indeed, the growth of rangaku had been causing concern amongst neo-Confucian scholars and government officials for some time. This is perhaps best exemplified by the famous 'Siebold affair' (1829), named after the aforementioned German physician and scholar, Philipp Franz von Siebold. He was found to be in possession of maps of Japan, which were considered forbidden material. Japanese teachers and students who had been in contact with Von Siebold, including Takahashi Kageyasu (1785-1829), a translator at the Tenmonkata, were arrested and imprisoned, and Von Siebold himself was placed under house arrest and then expelled from the country.

${ }^{13}$ Amongst these were Fukuda Sōtei, Takahashi Keisaku and Yanagida Teizō, who lived in villages around Nakanojō in the Gunma Prefecture in the middle of Honshu, the largest island in the Japanese archipelago.

14 The principal work that the Bansho Wage Goyō translated into Japanese was Algemeen huishoudelijk-, natuur-, zedekundig- en konst-woordenboek, a Dutch translation of Noël Chomel's French Dictionnaire oeconomique (1709). In fact only a partial translation into Japanese was achieved. This was given the title Kōsei shinpen ('Encyclopaedia for Household Use'). 
Despite such difficulties the interest in rangaku persisted, not least because it was recognized by some that this was the key to Japan retaining its sovereignty in the face of increasing Western imperialism in East Asia. They could point to the fate of China in the nineteenth century and argue that it was only by keeping up with Western technological advances mediated by books in Dutch that Japan could fend off potential invaders, although in some sense they failed in this. One telling statistic about the scale of this enterprise is that the library of the Japanese National Diet houses approximately 3,600 books that previously belonged to the Bansho Shirabesho ('Bureau for the Inspection of Barbarian Books'), founded in 1857, a successor to the Bansho Wage Goyo and similar organizations. Most of these books are in Dutch.

Yet it was at the very time that Dutch was gaining an increasingly important place in Japanese intellectual life that its position began to be challenged by the arrival in 1853 of the American, Commodore Perry. In 1854 the Convention of Kanagawa was concluded between America and Japan, a key step in the opening up of Japan to other Western countries.

\section{4. $1850-1890$}

However, as Hesselink has argued, the arrival of the Americans did not immediately signal the end for the Dutch language and rangaku in Japan. On the contrary, he writes,

The arrival of Commodore Perry boosted the importance of the role of rangaku. This was not limited to the reading of books in Dutch, but expanded to include highly visible careers for countless men in bakumatsu and Meiji society, who had, like Sakamoto Ryoma and Fukuzawa Yukichi, started their careers as rangakusha (Hesselink 2001: 208) ${ }^{15}$.

Furthermore, until 1870 Dutch was the language used for negotiations between the Japanese and foreign powers. The Americans and the British used Dutch, mainly through interpreters, in their first contacts with the Japanese. One such interpreter was Hendrik (Henry) C.J. Heusken (1832-1861). He was born in Amsterdam but his family had migrated to the United States. In 1856 he became the secretary and personal assistant to Townsend Harris (1803-1878), the first American consul-general in Japan. As well as using his Dutch to act as a linguistic bridge between the Japanese and Americans, Heusken also provided translation services to the Prussians in 1860-1861 (Hesselink 1994: 332).

In the new situation one of the Japanese who thrived was Ōkuma Shigenobu (1838-1922). He was born into a Samurai family near Nagasaki. He acquired an early knowledge of Dutch and English, which helped him to gain a position in

${ }^{15}$ Bakumatsu refers to the closing days of the Tokugawa Shogunate. This was followed by the Meiji period. 
dealing with foreign relations in Nagasaki after 1860 and he subsequently became a leading expert for the national government in financial matters and foreign affairs (De Bary 1958: II, 173).

The Dutch were involved in the establishment of the Japanese navy. The instruction of Japanese naval cadets by Dutch naval personnel in Nagasaki from 1855 to 1857 was given in Dutch and translated into Japanese by interpreters (Huyssen van Kattendyke 1860: 201). Dutch books on naval and military science were translated into Japanese. The Dutch naval engineer, H. Hardes, took charge of constructing a naval repair yard at Nagasaki, and another Dutchman, J.L.C. Pompe van Meerdervoort, a naval medical officer, oversaw the construction of the first military hospital in Japan (Blussé et al. (eds.) 2000: 183).

The close association between the Dutch language and Western medicine continued for a while after 1853. As late as 1879 Seki Gōsai (1844-1907), having passed his medical examinations, decided to go to Edo, by now called Tokyo, to study the Dutch language and rangaku. However, he was thwarted in his ambition for by now the heyday of rangaku had passed. Nine years earlier, in 1870, the Japanese government had decided that Western medicine would be introduced on the basis of a German model and German professors were invited to teach in Japan (Nakamura 2005: 167-168).

Elsewhere, the winds of change were blowing through Japan. In 1860 the Dutch trading post at Deshima was closed and replaced by a vice-consulate at Nagasaki (De Groot 2005: 2). The Japanese realized that there were more powerful nations in the world, such as America, Britain, Germany and France, with which they needed to engage. The last Dutch language book published in Japan in the nineteenth century was a translation into Dutch of the Japanese fairy tale, Shitakiri suzume. The naval engineer, Pieter Gerard van Schermbeek, spent time in Japan and published his translation as De musch met de geknipte tong ('The Sparrow with the Cut Tongue') in 1886 with illustrations by Sensai Eitaku. Tellingly, a dictionary of physics published in Japan in 1888 included terms in Japanese, English, French and German, but not in Dutch (Montgomery 2000: 222).

Nevertheless, this should not blind us to the fact that by this time Dutch had been written and spoken in Japan for nearly three hundred years. Furthermore, for over two hundred years it was the dominant European language in Japan.

It continued to be used for the commercial activities of the Dutch in Kyushu; it was studied by thousands of rangakusha at a number of schools in Japan; and was the medium through which countless books, primarily on natural science, were read and translated by Japanese scholars. This tells us that a social history of Dutch would be of value to Japanologists, neerlandici and others interested in this subject. The question then arises as to what approach should be adopted for such a social history. Possible answers to the question form the basis of the rest of this article. 


\section{What is a social history of language?}

However, before considering three possible approaches to writing a social history of Dutch in Japan we need to reflect briefly on what a social history of language is. One way of trying to understand the nature of a social history is to use a distinction made by Nevalainen \& Raumolin-Brunberg (2003: 16-17) in their study of Early Modern English between the sociology of language and sociolinguistics. Both explore the relationship between society and language, but whereas the sociology of language does so in order to understand society, sociolinguistics does so in order to understand language. Whilst their study focusses on the latter, the emphasis in a social history of Dutch in Japan should be on the former. To put it another way, consideration would primarily be given to external features, i.e., on how language relates to the context in which it is embedded, answering such questions as which languages does it compete with and what status it has in relation to other languages, rather than internal features such as grammar and syntax (cf. Burke 2005: 7). This is not to say that such a history should ignore internal features, merely that they will not be the focus of it.

However, in writing a social history on the use of Dutch in Japan we face a fundamental problem because there is something quite distinctive about that history, which means that it does not fit well into existing theoretical models. For example, in his study of the relationship between language and society in a contemporary context, Joshua Fishman writes that the aim is to understand "who speaks what language to whom and when' ${ }^{16}$. In a historical context such as the one being studied here, we of course need to talk in terms of 'who spoke...' However, whilst some of those who used Dutch in Japan did use it to speak to certain individuals or groups, others used their knowledge of Dutch primarily for writing or for reading in order to translate Dutch texts into Japanese. This of course does tell us something about the society in which these processes occurred, but it will be different from cases where the language is primarily used for speaking.

Some histories of language tell the story of the emergence of a standard language. This approach informs van der Wal \& van Bree's account of the history of Dutch (2008) and Lodge's account of the history of French (1993). Although a standard form of Dutch emerged during the period under review, the emergence of this standard form would not play a central role in an account of the history of Dutch in Japan.

Burke (2004) places the concept of communities of language at the centre of his study of the social history of language in early modern Europe. Whilst this concept will be valuable in a social history of Dutch in Japan, as discussed in the

${ }^{16}$ Quoted in Burke (2005: 6). 
next section, an approach that relies solely on communities of language would not be able to provide an adequate account of this subject ${ }^{17}$.

In what follows, this article evaluates the strengths and weaknesses of three possible approaches to writing a social history of Dutch in Japan, and then suggests that a combination of these approaches may be necessary.

\section{Three approaches to writing a social history of Dutch in Japan}

The first approach considers the history of Dutch in Japan in terms of communities of language, a notion which, as just discussed, has been employed in other social histories of language. The second approach is a domain-based approach, i.e., one that considers the use of Dutch in Japan within distinct social domains such as the work domain, education and the court. The third approach is a function-based one. As the name suggests this considers the various purposes for which a knowledge of Dutch was used, such as translation, interpreting and corresponding. Let us now consider each of these approaches in turn.

\subsection{Communities of language}

The first approach to writing a history of the Dutch language in Japan considers it in terms of communities of language. By this is meant groups of people who primarily use the same first language. In relation to Dutch in Japan there are three principal communities of language that can be identified. First, there are those who primarily used Dutch. This group consists of the Dutch and other Europeans based at the trading posts of Hirado and Deshima. A second group consists of Japanese scholars or rangakusha. They would primarily have used Japanese, but applied their knowledge of Dutch for the purpose of reading and translating out of the language into Japanese. A third community of language is the interpreters at Nagasaki. They, too, would primarily have used Japanese, but in contrast to the Japanese scholars they would have spoken both Dutch and Japanese when working as interpreters. As we shall see, there is some overlap between the second and third groups. Let us look at each group in a little more detail.

It is reckoned that over 800 Dutch ships sailed to Japan between 1609 and the early 1850s (Screech 2005: 75). About half of the hundred or so men on board each ship could be reckoned to be Dutch, so we can talk in terms of 40,000 Dutchmen (it was almost always men) arriving in Hirado and Nagasaki Bay during this period. To these we can add some of those non-Dutch who went ashore, and who

${ }^{17}$ It should be noted that Burke (2004: 5-7) does recognize that this concept is problematic. 
used Dutch as their first language in Japan. Amongst these we can count German physicians such as Caspar Schamberger discussed above. Andreas Cleyer (c. 1634-c. 1698), who was the head of the trading post at Deshima (opperhoofd) in 1682-1683, was born in Kassel in Germany. Another physician from Europe was the Swede, Carl Peter Thunberg. In December 1771 he left Holland as a ship's surgeon, and having spent three years in the Cape Colony in order to learn the Dutch language (as well as undertaking some botanical study), was able to pass himself off as a Dutchman. In August 1775 he arrived at Deshima and was appointed head surgeon of the trading post (1775-1776).

A second community of language that used Dutch were the rangakusha. There is relatively little evidence for these Japanese scholars engaging with books written in Dutch in the seventeenth and early eighteenth centuries ${ }^{18}$. However, as the eighteenth century progressed, the slow process of Japanese scholars engaging with books written in Dutch got under way (Boxer 1950: 54; Clements 2015: 150). The interpreters at Nagasaki played an important role in this process. Mention has already been made of the Yoshio, Motoki and Shizuki families of interpreters at Nagasaki, some of whose members engaged in scholarly research. This illustrates that there is some overlap between the rangakusha and the interpreters. Shogun Yoshimune also added impetus to this process by actively encouraging the study of the Dutch language (Nakamura 2005: 7). This is illustrated by the fact that in 1741 he sent the scholars Aoki Bunzō and Noro Genjō to Nagasaki in order to study the language. To this community of language we can also add the thousands of students of Western medicine in Japan in the late eighteenth and nineteenth centuries. Amongst these are the 5,000 or so students on the rolls of twelve famous schools of Western medicine, whose origins have been studied by Aoki Toshiyuki. We find the occasional piece of anecdotal evidence that tells us that tells us that scholars also spoke Dutch. To give one example here, Katsuragawa Hoshū, who became private physician to the shogun in 1783, spoke 'tolerable Dutch' at Edo with the physician on the Dutch side, the Swede, Carl Peter Thunberg (Screech 1996: 18).

A third community of language that used Dutch in Japan is the interpreters at Nagasaki. For much of the seventeenth century, it was not Dutch, but Portuguese

18 There are a few exceptions to this. For example, one of the Nagasaki interpreters, Motoki Ryōi (1628-1697), translated a Dutch edition of a work of anatomy by Johannes Remmelin, originally in Latin (Pinax Microcosmographicus, 1667) 'Microcosmic Diagrams'. He completed the translation in 1682, but it was not published until 1772, when it was given the title Oranda zenku naigai bungōzu ('Dutch Anatomical Map of the Human Body'). A book entitled Kōmōryū geka hiyō ('Secrets of Red-Haired Medicine') was completed in 1654. This was based on the oral teachings of a Dutch surgeon, translated by Nagasaki interpreters and transcribed by Mukai Genshō (16091677). Another Nagasaki interpreter, Narabayashi Chinzan (1648-1711), wrote a work, Kōi geka sōden, consisting of three fascicles, which was based on De Chirurgie ('Surgery') by Ambroise Paré (c. 1510-1590). This was completed in 1706, although it was never published (Boot 2013: 196-197; Clements 2015: 148). 
that was the medium of communication between the Japanese and the Dutch and there was only a handful of Japanese who knew Dutch. However, after 1673, when the Governor of Nagasaki ordered that boys aged ten to twelve were to visit Deshima to receive instruction in Dutch from members of the Dutch trading community on the island, the interpreters gradually shifted towards using Dutch in order to facilitate communication between the Dutch and their Japanese masters. The quality of the interpreters' Dutch was not always particularly good. The Germany physician, Engelbert Kaempfer, who lived and worked in Japan between 1690 and 1692, complained about the general standard of Dutch amongst the Nagasaki interpreters, and Hendrik Doeff, the opperhoofd at Deshima mentioned above, referred disparagingly to the interpreters' Japansch-Hollandsch ('Japanese Dutch') (Vande Walle 2001: 130-131; Doeff 1833: 24). One valuable insight into the quality of the Dutch that the Japanese used is offered by the correspondence between the opperhoofd, Isaac Titsingh, between 1785 and 1807 and a rangakusha, Kutsuki Masatsuna. This is discussed in more detail below.

As noted above, the lines between this community and that of the Japanese scholars cannot always be clearly drawn, as some of the interpreters were also engaged in scholarly research involving some of books written in Dutch. This lack of clarity is one of the drawbacks of using this approach to write a social history of Dutch in Japan.

Another drawback to this approach is that it is not always clear which group certain other individuals belong to, or whether a separate group needs to be created for them. For example, the Lord of Satsuma Shimazu Shigehide (1745-1833) acquired at least a smattering of Dutch. He was a daimyō, or local feudal ruler. Like his fellow daimy $\bar{o}$, he was keen to improve agriculture and exploit natural resources in his domain, so he provided financial support to rangakusha, as he considered that it would be useful to invest in these students to help them achieve this ${ }^{19}$. He might fit into the community of language of the interpreters in the sense that his primary language was Japanese, whilst also speaking some Dutch, but his purpose for using Dutch was quite different from that of the interpreters. A group of Japanese who do not fit easily into one of the groups described above are the orandayuki at Nagasaki. Literally, these are the 'women who go to the Dutch'. Some of them stayed faithful to given Dutchmen for extended periods and were considered by some of them as temporary spouses (Goodman 1986: 22-23). Furthermore, some of these women spoke Dutch quite well (Hesselink 1995: 200) ${ }^{20}$. Again, in theory they could be placed in the same community of language as the interpreters given that their

${ }^{19}$ In the dagregister for 1787 Shimazu Shigehide is recorded as having encountered the Dutch just outside Edo on the hofreis. He addressed the opperhoofd in 'broken Dutch' saying, 'Romberg, I have not seen you for a long time', a reference to Hendrik Caspar Romberg, who was opperhoofd intermittently between 1783-1790 (Hesselink 2005: 521).

${ }^{20}$ From 1639 onwards no Dutch women were allowed into Japan. In the first half of the nineteenth century some Dutch women came to Deshima, but they were sent away (Vos 1963: 342). One 
primary language was Japanese and they switched between Dutch and Japanese. However, as with the case of the Lord of Satsuma, their purpose for using Dutch was quite different from that of the interpreters, so it may seem inappropriate to place them in the same community of language as the interpreters.

One final point to make regarding communities of language is that for some commentators, notably Chomsky, linguistic homogeneity is vital to the identity of a community of language or 'speech-community' (Chomsky 1965: 3). In this regard, if we take the first community of language identified above, then we cannot talk of complete homogeneity. Particularly in the early part of our period, dialectal forms of Dutch were still dominant. Furthermore, the Dutch of other Europeans varied, at least in accent, from that of Dutch speakers, and Dutch was not the only language that they used. For example, when Carl Peter Thunberg discussed local flora with Japanese assistants, he would tell them the Dutch and Latin names (Thunberg 1784: xviii $^{21}$. Other commentators, such as Gumperz (1964), prefer to talk of a shared set of social norms as one of the factors determining the boundaries of given communities of language. In this regard, we can talk of homogeneity within the communities defined above. In the case of the Japanese interpreters, although the quality of their Dutch varied, they would know when to use Dutch and with whom, conforming to a given set of social norms within their particular community of language.

\subsection{A domain-based approach}

A second approach to studying language divides users into social domains. Joshua Fishman offers us a good definition of domains:

Domains are defined, regardless of their number, in terms of institutional contexts of socioecological co-occurrences... Domains enable us to understand that language choice and topic... are...related to widespread socio-cultural norms and expections ${ }^{22}$.

In deciding which domains to analyse one needs to consider what sources are available to research and how the particular society under investigation is organized. In a study on the use of Spanish and English in a contemporary American setting, Greenfield (1968) divided his material into five domains: family, friendship, religion, education and employment (Boxer 2002: 4). Domains can also be used to write about the social history of language. In his recent book on the Dutch language in early modern Britain, Joby (2015) divides material into the following domains: the church, the home, education, work, government of immigrant communities, the

of these, Titia Bergsma, visited Japan with her husband, Jan Cock Blomhoff, for several months in 1817. The Japanese were clearly taken by Titia and made numerous prints of her (Bersma 2002).

${ }^{21}$ Thunberg would later publish his account of Japan's plant-life, 'Flora Japonica', in Latin in Leipzig in 1784.

${ }^{22}$ Quoted in Boxer (2002: 4). 
royal court, the diplomatic domain, the military and literature. So, now we need to ask how effective such an approach would be for the study of Dutch in Japan.

In response to this question, we would have to begin by saying that there would be little value in analysing the material available using some of the domains just mentioned. After moving from Hirado to Deshima, the Dutch struck a secret deal with the Japanese authorities that they could only continue to trade with Japan as long as they did nothing to promote the Christian religion. There was no church on Deshima, and although some of those who lived on the island are likely to have worshipped privately, there would be little value in studying the use of Dutch within the domain of the church or religion more broadly ${ }^{23}$. As for the home, we have private letters that were written in Dutch. There is also evidence that the Dutch used their native language in talking with the interpreters in this domain and indeed with the orandayuki who visited and even stayed in their homes. However, it would not be profitable to devote an entire chapter to the use of Dutch in this domain. On the other hand we could usefully analyse the writing and speaking of Dutch in the commercial domain. It was, after all, for reasons of commerce that the Dutch were in Japan. Furthermore, there is plenty of evidence for the use of Dutch in this domain. For example, we have factory journals or dagregisters from 1633 onwards. These were usually kept by the opperhoofd and provide a detailed account in Dutch of daily life at Hirado and then Deshima. They also provide metalinguistic comment, i.e., details about the use of language in given situations, such as the knowledge of Dutch of individual Japanese who had contact with the Dutch trading post. Correspondence and personal diaries such as the one kept by the opperhoofd, Hendrik Doeff, provide further evidence of the use of Dutch in this domain (Doeff 1833). All these sources give us useful information about the effects of language contact, such as code switching, a subject discussed in more detail in section 6 below.

Another domain in which Dutch was used was the court and diplomatic domain. Several sources provide evidence that Dutch was used in a variety of situations within the context of the hofreis. One of these is the dagregisters, just mentioned. Personal journals kept by the Dutch and other Europeans on the hofreis, such as that kept by Carl Peter Thunberg, provide further evidence of the use of the Dutch language in this domain.

When we turn to the domain of education things are more complex. One area of study within this domain should be the processes by which the interpreters at Nagasaki (tsüji) acquired their knowledge of Dutch. This happened in a number of ways. First, older apprentices and adult interpreters would often learn Dutch by rote under instruction from more senior Japanese interpreters in the tsüji nakama. Second, young boys would be sent to Deshima to learn Dutch from members of the

23 The Dutch managed to bring Bibles and other religious works into the country sealed in a barrel whenever a ship arrived. However, these would necessarily have had to remain for private use (Vos 1989: 356). 
Dutch trading community on the island. We have already seen that in 1673 the Governor of Nagasaki ordered that boys aged ten to twelve were to visit Deshima for this purpose. Entries in the dagregister after this indicate that the practice of sending young boys to Deshima for instruction in Dutch continued into the eighteenth century, although there may have been times when it did not happen. Third, the interpreters typically came from families of interpreters and would often inherit this position from their fathers. On the one hand, this means that they were not always skilled in interpreting, but on the other hand it suggests that they may have picked up some knowledge of Dutch from their fathers.

A second focus of attention in the domain of education would be the various schools established in the late eighteenth and nineteenth centuries devoted to the study of rangaku and the Dutch language. To the schools established by Ōtsuki Gentaku, Yoshio Kōgyū and Philipp Franz von Siebold, we can add the schools of Western medicine studied by Aoki Toshiyuki, discussed above.

Indeed, there was a close relationship between learning Dutch and acquiring knowledge of Western medicine, for many of those who learnt the language did not really do so in order to be able to speak it and communicate with native speakers, but, rather, in order to gain knowledge of various branches of Western science, with which they could come into contact by reading books written in Dutch. It should be noted that many of these books were not originally written in Dutch but were translations from other European languages. As the Dutch were the only Europeans allowed to trade with the Japanese between 1641 and 1853/54, it was almost exclusively books written in Dutch that were imported into Japan. These would be studied and translated into Japanese by rangakusha. Some of these are amongst the 3,600 or so books in Dutch that are now preserved in the library of the Japanese National $\operatorname{Diet}^{24}$. And here we come to one of the principal problems with analysing the use of Dutch in Japan by social domain. As noted above (section 3), the aim of this approach to analysing the use of language is neatly encapsulated in the formula provided by Joshua Fishman: 'who speaks what language to whom and when'. However, outside the Dutch trading posts and visits to Edo, the principal reason for which a knowledge of Japanese was acquired was not to speak the language, nor to write it to any great degree, but rather to read and translate it into Japanese in order to access the information about Western science that it transmitted. In this regard, Tetsuo Najita has written 'Dutch was a language to translate, not to theorize with' (Najita 1991: 634) ${ }^{25}$.

One way of considering Dutch in this context is as a 'metalect', i.e., a language that mediates knowledge. In some sense the use of Dutch for this purpose has something in common with the study of classical Chinese in Japan. Although words may

24 http://www.ndl.go.jp/nichiran/e/s1/s1_3.html. Accessed 19 March 2017.

25 Quoted in Nakamura (2005: 3). In a similar vein, the rangakusha, Sugita Gempaku, observed that Dutch was a language that expressed facts (De Bary 2013: 369-371). This clearly had much to do with the type of book that he and other rangakusha were translating into Japanese. 
well have been exchanged in this language in everyday communication, it was studied primarily for the knowledge that it transmitted. This being so, we need to ask different questions than those typically posed in social histories of language. For example, what material was translated; what approaches were used for translation; how successful were these translations, both in terms of accuracy and the number of people who read them; and did the process of translating books from Dutch to Japanese have an effect on the latter either at a lexical or syntactic level? One approach that may allow us to address such questions is a functional approach, i.e., one that considers the various purposes for which Dutch was used in Japan. Let us now consider this third approach to writing a social history of Dutch in Japan in a little more detail.

\subsection{A function-based approach}

Two important functions for which Dutch was used in Japan were translation and interpreting. Alongside these we can place reading Dutch, corresponding and record-keeping in the language. Verbal communication involving the Dutch or people who used Dutch as their principal spoken language in Japan, such as the non-Dutch European physicians mentioned above, is another function to be considered.

Many books were translated from Dutch into Japanese for the purpose of developing an understanding of Western science amongst rangakusha. Two branches of science in which many books were translated were medicine and astronomy. In the field of medicine, it was particularly anatomy that was of interest to the Japanese. One early example of this was Kaitai Shinsho (1774), mentioned above, which was translated into Japanese from the Dutch translation of a Latin edition of a work on anatomy by Johann Adam Kulmus. Books on astronomy include those translated at the Bansho Wage Goyō from 1811 onwards. Physics and geography were two other fields in which Dutch books were translated into Japanese.

Not all the rangakusha translated Dutch books into Japanese. Some simply read them in order to understand the Western science that these books transmitted. This is the case for some of the rangakusha who attended the rangaku schools described above. So the process of reading on its own must be seen as one of the functions involving the Dutch language in Japan. However, providing evidence for reading may not be straightforward.

Another function performed by those who had a knowledge of Dutch was interpreting. Above, there was a brief discussion of how some of the Japanese interpreters at Nagasaki learnt Dutch. By the end of the seventeenth century, Dutch had effectively replaced Portuguese as the language through which the Japanese communicated with the Dutch and other Europeans at Deshima. In part because of a ban on the Dutch learning Japanese, Dutch continued to be the language through which the Dutch and Japanese communicated via interpreters until the end of the 
Dutch monopoly on trade with the West in the 1850s. It was also used as the language of interpretation for the Americans and other Europeans and the Japanese in the years after 1853, as the case of Hendrik Heusken illustrates.

Dutch was used for correspondence. Typically, this was written by the Dutch or other Europeans at Hirado or Deshima. However, Japanese, too, occasionally composed letters in Dutch; for example the rangakusha, Kutsuki Masatsuna. Between 1785 and 1807 he corresponded in Dutch with Isaac Titsingh, the opperhoofd at Deshima intermittently between 1779 and 1784 . One passage from a letter that Masatsuna wrote in 1787 to Titsingh, now the head of the Dutch trading post at Chinsura in Bengal, illustrates that he had not yet mastered the language:

Aan de WelEdele Heer Titsingh, Directeur van Bengale...UwEdele misive, uit handen van den Heer Romberg door bestelling de Heer Ulps met hem brief laat ontfangen, en het mijn beantwoord voor het afschrift van uE: brief van aan den Tolken...

Rather touchingly Masatsuna would ask Titsingh to correct his written Dutch (Lequin 1992). Records such as the dagregister at Hirado and Deshima were kept in Dutch, as were the accounts for the trading post.

One other function that Dutch fulfilled in Japan was for the purpose of verbal communication. Typically this would be between two or more people whose first language was Dutch, although of course dialectal variation was still strong, particularly in the early part of the period under consideration. Dutch also functioned as a lingua franca between the Dutch and others at Deshima. Officially, from 1641 onwards the Dutch were the only Europeans allowed to enter Deshima and trade with the Japanese. However, there were several groups of people at Deshima who were not Dutch. One of these comprises the physicians from other European countries, notably Germany. Several of the Japanese realized that there was something different about the Dutch accent of one of them, Von Siebold. In order to explain this he was referred to as a yama orandajin, i.e., a 'mountain Dutchman'! Based on the figures given above, we can estimate that about 40,000 of the VOC crewmen who sailed to Hirado and Nagasaki Bay were not Dutch. However, our current state of knowledge does not allow us to say how many of them disembarked and spoke Dutch at Hirado or Deshima.

In conclusion, though, we can say that there is evidence that Dutch was used to fulfil several distinct functions in Japan.

\section{An evaluation of the three approaches}

The article now gives brief consideration to the question of which of the three approaches described above would be most appropriate for a social history of Dutch in Japan. What emerges is that it might be better to adopt a mixed economy, i.e., a methodology that incorporates aspects of each of these approaches. 
The activities of those in the community of language consisting of the Dutch and non-Dutch Europeans could best be described within the framework of social domains. The most notable domain in which they participated, and the one for which we have the most evidence, is the commercial domain. To these we can add the court and diplomatic domains, notably in relation to the hofreis to Edo. Although details of the use of Dutch in the home are somewhat limited, it is nevertheless a domain that needs to be discussed. One activity that could be described in this context is the educating of young boys in the Dutch language in the homes of the Dutch on Deshima. However, the fact that this could also be considered within the domain of education illustrates that it is sometimes not possible to place one activity entirely within one domain.

Turning to the rangakusha, we can say that the primary domain in which they were active was that of education, which could be broadened to some extent to include learning. However, much of their engagement with the Dutch language involved the function of translation. Given the extent of this activity and the specificity of the manner in which Dutch was used in this process, the function of translation would merit a separate chapter within a history of the Dutch language in Japan.

As for the interpreters, their activities would also need to be analysed within the domain of education. They received education in the Dutch language, as discussed above, from the Dutch at Deshima, and more senior Japanese interpreters would pass on their knowledge of the language to younger interpreters either within the family or in the more formal context of the tsüji nakama at Nagasaki. Although in theory it might be possible to treat the function of interpretation separately in the same way as that of translation, it may be more appropriate to provide an initial account of the interpreters in an introductory chapter on Dutch in Japan, and then consider their activities within the social domains in which they took place, such as the commercial, educational and court domains.

\section{Linguistic themes}

Before concluding a word is in order about some of the linguistic themes that need to be addressed in a social history of Dutch in Japan. The question of what sort of Dutch the Japanese used requires further investigation. Metalinguistic comment from Dutchmen such as Hendrik Doeff and the example from Kutsuki Masatsuna's correspondence illustrate that the Dutch of some Japanese was far from perfect. Further examples will need to be presented to gain a more comprehensive understanding of the Dutch used by the Japanese.

The consequences of language contact will also require attention. We know that over 300 Dutch words were adopted by Japanese (e.g., van der Sijs 2006: 117; Vos 1963: 359-371; Irwin 2011). However, little work has been published on how this happened and what the adoption of these loanwords tells us about social relations 
between the Dutch and Japanese. Although the focus of the proposed history will not be on internal features of language, it will also need to examine whether and to what extent language contact also influenced Japanese on a structural level, a subject that has not yet received the attention of historians of the Dutch language ${ }^{26}$. Going the other way, a smaller number of Japanese words were adopted by Dutch. Van der Sijs (2006: 99, 160) provides examples of these, such as the drink sake, and moksa, a medicinal herb used in acupuncture. However, more will need to be said on this subject.

We should also look at code switching. Texts written in Dutch by European and Japanese authors often transliterate Japanese terms. For example, Kutsuki Masatsuna would date his letters to Isaac Titsingh with transliterated versions of Japanese names for months, e.g., sanguats for the third month and rokguats for the sixth month (sangatsu and rokugatsu respectively in modern Japanese). The proposed social history of Dutch in Japan will try to identify patterns for this code switching, and examine the motivation behind it.

Another subject of interest to linguists is the social prestige attached to a language. A social history of Dutch in Japan will need to consider whether Dutch was a high-prestige $(\mathrm{H})$ or low-prestige (L) language. In this regard Burke (2014: 34) writes 'what most concerns a social historian is the use of language to mark differences in social statuses or social situations'. One suggestion by De Groot (2005: 26-27) that requires further investigation is that the slowness with which the Nagasaki interpreters shifted from Portuguese to Dutch can in part be attributed to the fact that many of them belonged to the Samurai class who considered the Dutch merchants at Deshima to be socially inferior to them. It will also be useful to investigate the status of Dutch during the period after 1853 when it had to compete with other Western languages.

Finally in this regard, this article has provided some quantitative data of interest to linguistics such as the number of Dutch in Japan; the average number of interpreters at Nagasaki; the number of translations from Dutch to Japanese in certain years; and the number of Japanese students on the registers of rangaku schools. However, there is more work to be done in this regard. The proposed social history would provide other quantitative data on, for example, how long the Dutch typically stayed in Japan; how many of the non-Dutch crew members who sailed to Nagasaki knew Dutch; and, where possible, the social rank of the Japanese who used Dutch.

\section{Conclusion}

In conclusion, it is clear that writing a social history of Dutch in Japan presents several challenges. For this reason it has been appropriate to write an exploratory

${ }^{26}$ See Earns (1996), Vos (1963: 383) and Frellesvig (2010: 410). 
article, which tries to map out what sort of social history could be produced. Certain aspects of this story fall into the well-established framework of providing an account of language use within social domains. However, the process of translating books from Dutch to Japanese does not fit so well into this framework and needs to be treated separately. One approach to writing this history would be to provide an introductory chapter, which provides a history of Dutch in Japan, indicating who knew the language, and which introduces the principal themes of the book. The following chapters could then be devoted to a study of the use of Dutch by social domain. A final chapter would consider the function of translation. This would look at what material was translated from Dutch to Japanese; the effect of the material translated on Japanese society; and how translation into Japanese affected the language on both a lexical and syntactic level. Such a book would offer a novel approach to the writing of the social history of language, addressing the particularity of the use of the Dutch language in Japan. Should this approach achieve some success, then it could offer a methodological template for writing the history of other languages, which do not easily fit into one of the existing approaches. However, it would also, it is to be hoped, contribute to our understanding of the use of Dutch in Japan in the seventeenth, eighteenth and nineteenth centuries, a subject which to date has received relatively little scholarly attention.

\section{References}

Bersma, R.P. (2002). Titia. The First Western Woman in Japan. Amsterdam: Hotei.

Blussé, L. et al. (eds.) (2000). Bridging the Divide: 400 years The Netherlands-Japan. [Leiden]: Hotei.

Boot, W.J. (ed.) (2008). The Patriarch of Dutch Learning Shizuki Tadao (1760-1806). Volume 9 of Journal of the Japan-Netherlands Institute. Tokyo: The Japan-Netherlands Institute.

Boot, W. (2013). "The Transfer of Learning. The Import of Chinese and Dutch Books in Togukawa Japan”, Itinerario XXXVII (3), pp. 188-206.

Boxer, C. (1950). Jan Compagnie in Japan, 1600-1850; An Essay on the Cultural, Artistic and Scientific Influence Exercised by the Hollanders in Japan from the Seventeenth to the Nineteenth Centuries. The Hague: Nijhoff.

Boxer, D. (2002). Applying Sociolinguistics: Domains and Face-to-face Interaction. Philadelphia: John Benjamins.

Burke, P. (2004). Languages and Communities in Early Modern Europe. Cambridge: CUP.

Burke, P. (2005). Towards a Social History of Early Modern Dutch. Amsterdam: AUP.

Burke, P. (2014). "Diglossia in Early Modern Europe", [in:] European Francophonie: The Social, Political and Cultural History of an International Prestige Language, ed. V. Rjéoutski, G. Argent and D. Offord. Bern: Peter Lang, pp. 33-50.

Chomsky, N. (1965). Aspects of the Theory of Syntax. Cambridge, Mass.: The MIT Press.

Clements, R. (2015). A Cultural History of Translation in Early Modern Japan. Cambridge: CUP.

Clulow, A. (2014). The Company and the Shogun: The Dutch Encounter with Tokugawa Japan. New York: Columbia University Press.

De Bary, W.T. (1958). Sources of Japanese Tradition: Volume 2, 1600 to 2000. New York: Columbia University Press. 
De Bary, W.T. (2013). Sources of Japanese Tradition: Volume 2, 1600 to 2000. New York: Columbia University Press.

De Groot, H. (2005). The Study of the Dutch Language in Japan During its Period of National Isolation (ca. 1641-1868). Christchurch, New Zealand, PhD. Thesis.

De Lange, W. (2006). Pars Japonica. The First Dutch Expedition to Reach the Shores of Japan. Warren, CT.: Floating World Editions.

De Vries, P. (2002). "Het Leven van Dirck Gerritsz Pomp alias Dirck China", [in:] Dirck Gerritsz Pomp alias Dirck China, ed. K.W.J.M. Bossaers. Enkhuizen: Vereniging Oud Enkhuizen, pp. $7-24$.

Doeff, H. (1833). Herinneringen uit Japan. Haarlem: De erven François Bohn.

Earns, F. (1996). "Dutch Influence on the Japanese Language at the Syntactic Level", Asian Culture, 24:1, pp. 64-71.

Frellesvig, B. (2010). A History of the Japanese Language. Cambridge: CUP.

Goodman, G.K. (1986). Japan: The Dutch Experience. London: The Athlone Press.

Greenfield, L. (1968). "Spanish and English Usage Self-ratings in Various Situational Contexts", [in:] The Measurement and Description of Language Dominance in Bilinguals. Seventh Progress Report, ed. J. Fishman. New York: Yeshiva University.

Groeneboer, K. (1998). Gateway to the West: The Dutch Language in Colonial Indonesia: A History of Language Policy. Amsterdam: AUP.

Gumperz, J. (1964). "Linguistic and Social Interaction in Two Communities", Language, Culture and Society, 14, ed. B. Blount, pp. 283-299.

Hesselink, R. (1994). "The Assassination of Henry Heusken", Monumenta Nipponica, 49:3, pp. 331-351.

Hesselink, R. (1995). “A Dutch New Year at the Shirandō Academy 1 January 1795”, Monumenta Nipponica, 50:2, pp. 189-234.

Hesselink, R. (2001). (Review). "Grant K. Goodman, Japan and the Dutch 1600-1853 (Richmond, Surrey: Curzon Press, 2000)", Journal of Asian History, 35,2, pp. 206-208.

Hesselink, R. (2005). 'A New Guide to an Old Source', Monumenta Nipponica, 60:4, pp. 513-523.

Huyssen van Kattendyke, W.J.C. (1860). Uittreksel uit het dagboek van W.J.C Ridder Huyssen van Kattendyke, kapitein-luit. ter zee, gedurende zijn verblijf in Japan in 1857, 1858, en 1859. The Hague: W.P. van Stockum.

Irwin, M. (2011). Loanwords in Japanese. Amsterdam: John Benjamins.

Joby, C.R. (2015). The Dutch Language in Britain (1550-1702). Leiden: Brill.

Lequin, F. (1992). The Private Correspondence of Kutsuki Masatsuna and Isaac Titsingh (17851807). Amsterdam: J.C. Gieben.

Lodge, R.A. (1993). French: From Dialect to Standard. London: Routledge.

Montgomery, S.L. (2000). Science in Translation: Movements of Knowledge through Cultures and Time. London: University of Chicago Press.

Najita, T. (1991). "History and Nature in Eighteenth-Century Tokugawa Thought", [in:] The Cambridge History of Japan, vol. 4, Early Modern Japan, ed. J.W. Hall. Cambridge: CUP, pp. 596-659.

Nakamura, E.G. (2005). Practical Pursuits: Takano Choei, Takahashi Keisaku, and Western Medicine in Nineteenth-Century Japan. Cambridge, Mass.: Harvard University Asia Center.

Nevalainen, T. and H. Raumolin-Brunberg. (2003). Historical Sociolinguistics: Language Change in Tudor and Stuart England. London: Pearson.

Rangaku Shiryō, K. (1957). List of Foreign Books Collected under the Shogunate Regime. Tokyo: Japanese Society for the Study of Dutch Learning (Reprint 1969).

Sansom, G.B. (1973). The Western World and Japan: A Study in the Interaction of European and Asiatic Cultures. New York: Vintage Books.

Neerlandica Wratislaviensia 26, 2016

(C) for this edition by CNS 
Screech, T. (1996). The Western Scientific Gaze and Popular Imagery in Later Edo Japan: The Lens with the Heart. Cambridge: CUP.

Screech, T. (2005). Japan Extolled and Decried: Carl Peter Thunberg and the Shogun's Realm, 1775-1796. London: Routledge Curzon.

Thunberg, C. (1784). Flora Japonica. Leipzig: I.G. Mullerianus.

Van der Sijs, N. (2006). Calendarium van de Nederlandse Taal: De geschiedenis van het Nederlandsin jaartallen. The Hague: SDU Uitgevers.

Van der Wal, M. and C. van Bree. (2008). Geschiedenis van het Nederlands. Utrecht: Spectrum.

Vande Walle, W.F. (2001). "Linguistics and Translation in Pre-Modern Japan and China: A Comparison", [in:] Dodonaeus in Japan: Translation and the Scientific Mind in the Tokugawa Period, ed. W.F. Vande Walle. Leuven: Leuven University Press, pp. 123-147.

Vermeulen, T. et al. (eds.) (1986-). The Deshima dagregisters, 13 vols. Leiden: Leiden Centre for the History of European Expansion.

Vos, F. (1963). "Dutch Influences on the Japanese Language", Lingua, 12, pp. 341-388.

Vos, F. (1989). "Mihatenu Yume-An Unfinished Dream: Japanese Studies Until 1940”, [in:] Leiden Oriental Connections 1850-1940, ed. W. Otterspeer. Leiden: Brill, pp. 354-377.

Willemyns, R. (2013). Dutch: Biography of a Language. Oxford: OUP. 